\title{
Gender Discrimination In Selection On Bureaucratic Jobs: A Case Study Of Sindh Public Service Commission
}

\author{
Zahid Ali Channar \\ Faculty of Management, Business Administration \& Commerce \\ Sindh Madressatul Islam University \\ Sakina Riaz \\ Department of Social Work \\ University of Karachi \\ Saleem Raza Quresh \\ Department of Management Sciences \\ Isra University
}

\begin{abstract}
This research has focused on gender discrimination in selection on bureaucratic jobs through Sindh Public Service Commission (SPSC). The study was conducted on secondary data collected from annual reports of SPSC.The data was analyzed by the Management tool (fourth-fifths rule)and Statistical technique (Chi-square goodness of fit test). Analysis through $4 / 5^{\text {th }}$ rule showed that in the combined competitive examination of year 2011, there was huge gender discrimination against females in the appointments of Deputy District Officers' posts; and for the appointment on the posts of Section Officer, females were again discriminated as compared to males.Gender Discrimination in the appointment on the bureaucratic jobs was also assessed through Chi-Square goodness of fit test. Results yielded by the test showed that there was huge discrimination against females on the appointment of all bureaucratic jobs. This research has implications for the Government, Human Rights Activists and educated females.
\end{abstract}

Keywords: Gender, Discrimination, Sindh Public Service Commission, Bureaucratic Jobs.

\section{تثاخص}

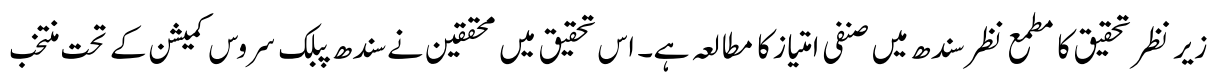

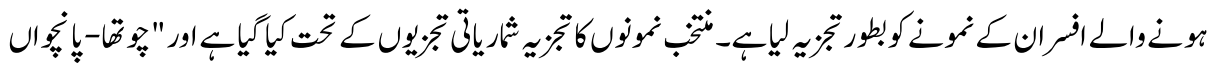

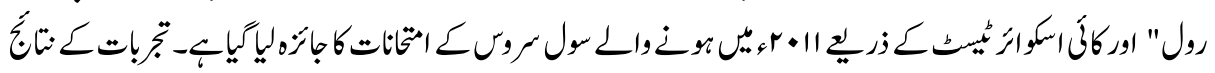

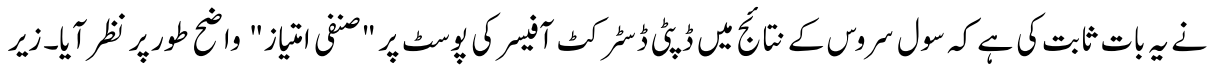

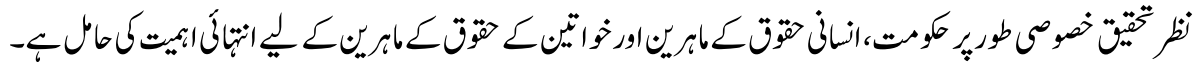

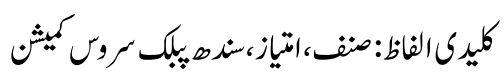




\section{Introduction}

Pakistan is among those countries where culturally, a subordinated social status is attached with women, which turns her vulnerable and shrinkingposition in society. Due to this discouraging situation, women has suffered a lot with mental and physical stress, absence of appropriate balance between work and family care, prejudiced treatment in the workplace, and gender discrimination. The term "gender discrimination" is refer as the unfair treatment of a person because of gender. Gender discrimination touches both men and women equally. Discrimination in employment takes place when any organization, persons, or governments take care of people in a different way because of their individuality like race, gender, or sexual orientation instead of their aptitude to do the job.Or one gender gets a smaller amount in terms of salary or job duties because of gender biased stereotypes and unfairness. According to Decenzo et al., (1996), "HRM is concernedwith the staffing, training, development, motivation and maintenance of employees working in the organization. Staffing of employees is done through job analysis which is an organized process of gathering information used to categorize the responsibilities of each job (Gomez et al., 2005). Gender discrimination in the provision and use of resources is not uncommon in the workplace even in the more developed countries (Crosby, 1984; Ensher, Grant- 112 Sadia Shaukat, Aishah Siddiquah, \& Anthony William Pell Vallone, \& Donaldson, 2001; Greenhouse, 2004, Shauka, S., Siddiquah, A., \& Pell, W.A, 2014). Further, gender disparities are specifically flagrant in the workplace. For example, typically women are preferred to work part-time basis, be employed in less-paid jobs and not take on management positions (Arulampalam et al, 2007, European Union, 2014).

In United States the major law regulating equal employment opportunity is the Title VII Civil Rights Act of 1964 (Noe et al., 2001). In 1972, congress passed an amendment to the legislation called Equal Employment Opportunity Act (Decenzo et al., 1996). It was established to remove the differences made by managers among its employees (Gomez et al., 2005). The idea of EEO can be liberal approach and radical. In Liberal approach equality is maintained among employees of the organization. Purpose of Radical approach is to make sure that organizations must follow the policies of affirmative action (Ali et al., 2008). Organizations used affirmative action program to prohibit and remove past discrimination (Noe et al., 2001). It is mainly used by government agencies and businesses (Gomez et al., 2005).

In the last 30 years, development process has gone through dramatic changes throughout the world. Similarly in Pakistan ,since 1980s an extensive range of governance reforms have been familiarized for improvement in public sector performance, economic growth, poverty reduction, citizen participation, greater accountability and transparency. Pakistanhas also made some progress in terms of representation of women in governance 
in the recent past (Jabeen, N. \& Muhammad Zafar, 2010). Pakistan agreed to the UN Convention on the Elimination of All Forms of Discrimination against Women (CEDAW) signed in 1996 (UN report on CEDAW,2011).

In Pakistan women have always been discriminated in every walk of life. According to the World Economic Forum's Global Gender Gap Report 2017, Pakistan (143) remains the region's lowest-ranked country and second-to-last ranked overall. It records some progress on closing the basic literacy gender gap, and on women's labour force participation (World Economic Forum, 2017: 23). Pakistan's refined labour participation rate86 of 21.5 per cent for females (UNICEF, 2012). As per the recent report of United Nations Development Program (UNDP,2015).Pakistan ranks 121st out of 155 countries in terms of its Gender Inequality Index.Though,employment opportunities have become much better in Pakistan but still there is gender inequality as women have less access of labor market opportunities and improper conditions of working environment. It is more difficult for women to find a decent job than men. It is important for women empowerment to give themthe opportunity, resources, employment, political decision making, and quality education (Saigol, 2011).

Gender discrimination in public sector organizations of Pakistan is obvious that ministries have no female employees as per quota decided by the Government and they are not given promotions on time as well (Kiani K., 2011). Hence, as a matter of fact gender discrimination is quite common and well-documented in Pakistan (Kazi, 2011; IqbalH , et al 2012; Delavande, A. \&Zafar, 2013). While, this discrepancy in the public services is also common in South Asian countries like India, Pakistan and Bangladesh women underrepresented in higher decision making levels (Kabir, 2013).

The concept of Discrimination in employment is viewed as differences among individuals. In the perspective of Human Resource Management, it means differences among people (Gomez et al., 2005). According to Michalle (2011) ILO has cleared that there should not be any kind of segregation. No one should be given preferences because they belong to a particular class, race, gender, origin, religious belief etc. Biased attitude must be avoided which damage equal opportunity in employment. According to Imasogie M. (2010) "it is clearly stated by the Convention on the Elimination of Discrimination against Women that the gender discrimination must be avoided as it affects the status of women in the society. Women must be given equal opportunity of employment despite of being married or having children. Men and women both should have equal access of fundamental rights in each and every walk of life".

\section{Literature Review}

According to the Gender Gap Report (2016) "the global gender gap across education and economic opportunity and politics in the last 10 years has almost by $4 \%$, whereas the 
economic gap has closed by 3\%".According to Mor Barak \& Michelle E. (2011) Discrimination in employment takes place when any organization, persons, or governments take care of people in a different way because of their individuality like race, gender, or sexual orientation instead of their aptitude to do the job and these measures impact the employees negatively in achieving promotions, or compensation. Legal researchers have given three theories on discrimination (Noe et al., 2001), which are:

1. Disparate treatment

2. Disparate impact

3. Reasonable accommodation

Disparate Treatment: It is a theory of discrimination. This is an intentional discrimination. It is based on unusual dealing with individuals because of their caste, creed, gender, origin, or disability (Dressler G., 2007). If a manager discriminates among employees because of the above mentioned characteristics then it means disparate treatment has taken place in the organization (Gomez et al., 2005). Forexample: A woman with children was refused for the job in an organization but a man with children was hired for the same job by the manager (Dressler G., 2007). In this situationthe applicant has to prove that discrimination has occurred (Dressler G., 2007). Applicant meets prima facie burden by showing four things (Noe et al., 2001) and may follow the following procedure:

a. Applicant should belong to a protected class

b. Applicant was eligible

c. But discarded by the employer

d. Employer continues seeking or hires someone else with similar qualification.

Once applicant proves the prima facie, then employer has to provide a circumstantial evidence. It is not a direct evidence of discrimination. The employer simply produce legal reason that person hired was more qualified than applicant. If employer proves nondiscrimination then applicant has to prove that reason given by employer is just an excuse (Noe et al., 2001).

Disparate Impact: It is also a theory of discrimination (Noe et al., 2001). It is also known as the adverse impact. It takes place when employer has same behavior with everyone in his staff although somehow it has negative influence on some workers (Gomez et al., 2005). It means employer has discriminated one group than the other (Dressler G., 2007).For example:A company hires employees based on their height then women will be hired less because women are generally of shorter height as compared to men. This will have a negative impact on women. Under this situation the applicant has to prove that employment practices are affecting protected class or group more as compared to the majority group (Noe et al., 2001). The employer can show that such 
employment practice is a business necessity. Business necessity is like a defense. It is formed by the courts. It shows that there is a business need or purpose behind the discrimination (Dressler G., 2007).

Reasonable Accommodation: It is a new theory of discrimination. It is a duty of an employer to accommodate those employees; who are physically disabled or belong to a minority or a protected group. But if an employer fails to keep equality among employees because of their religion, physical disability etc. then this theory is being violated (Noe et al., 2001).

\section{Equal Employment Opportunity}

It is a result of government's struggle to provide equal opportunity of employment ${ }^{1}$ to one and all, regardless of their belief, culture, creed, color, origin, or gender. In United States the major law regulating equal employment opportunity is the Title VII Civil Rights Act of 1964 (Noe et al., 2001). In 1972, congress passed an amendment to the legislation called Equal Employment Opportunity Act (Decenzo et al., 1996).It was established to remove the differences made by managers among its employees (Gomez et al., 2005). Laws of equal employment opportunity are not essentially alike in every country (Noe et al., 2001).For example in Japan, the analysis about career track of 1990s, shows little effect of the law on female employment (Abe 2010, 2011). The idea of EEO can be liberal approach and radical. In Liberal approach equality is maintained among employees of the organization and discrimination is avoided completely when both women and men are judged on same grounds. Purpose of Radical approach is to make sure that organizations must follow the policies of affirmative action (Ali et al., 2008).

Following are themajor Equal Employment opportunity laws that affect human resource issues at work place (Gomez et al., 2005):

- $\quad$ The Equal Pay Act of 1963

- $\quad$ Title VII of the Civil Rights Act of 1964

- $\quad$ The Age Discrimination in Employment Act of 1967

- $\quad$ The Americans with Disabilities Act of 1990

All these above laws are based on one concept and that is to provide equal employment opportunity to everyone whether they belong to any race, sex, or age.

\section{Human Resource Laws Related with Gender Discrimination: An overview}

\section{The Fourth-Fifths Rule}

It is also known as the "Rule of Thumb". It is established by the standardized procedure on worker assortment measures. ${ }^{2}$ It is a practical device to keep an eye on serious issues 
regarding employment decisions (Decenzo et al., 1996). According to fourth-fifths rule there is a tendency of disparate treatment in the organization. Forinstance, in case the manager has not appointed the applicant of protected group in accordance with fourthfifths, means $80 \%$ of the employing tempo for the majority group (Noe et al., 2001). It is referred as a disparate rejection rates (Dressler G., 2007). For example: An applicant pool of the organization consists of white candidates which are 80 and black candidates which are 40 respectively. After the examination organization hired forty eight white applicants and 12 black applicants. Disparate impact is proved by the fourth-fifth rule:

White applicants $=48 / 80=60 \%$

Blacks applicants $=12 / 40=30 \%$

This shows adverse impact against black applicants (Noe et al., 2001).

\section{Restricted Policy}

It is a test which analyzes adverse impact. It is used to find that whether discrimination was done intentionally or unintentionally (Dressler G., 2007). It takes place when policies of organization ignore a class of individuals (Decenzo et al., 1996).

\section{Population Comparison or Geographical Comparison}

It is used to compare the percentage of the minority group or qualified applicants with others in the labor market or their existing employees (Dressler G., 2007). If the characteristics of both groups are same then organization is in the compliance (Decenzo et al., 1996).

\section{Mc. Donnell-Douglas Test}

This test is used to show that the applicant was suitable according to the post but discarded and employer kept the post open and continued to look for other applicant. This is used to show the disparate treatment. The U.S. court has put four conditions to use this approach (Dressler G., 2007):

a. Applicant must belong to a protected class

b. Applicant must be qualified for the job

c. Applicant was rejected despite of being applicable

d. After rejection employer kept looking for others

\section{Griggs v. Duke Power}

It is concerned with employment discrimination and adverse impact ${ }^{3}$.If the courts find that company is discriminating because of some business requirement or business need 
(Noe et al., 2001) than necessary decision will be given to deal the situation.For example: Male persons are hired for male restroom.

Studies on women's on gender discrimination in job opportunities have indicated that sex is a common barrier for women's career advancement in the academic workplace; institutional factors contribute to gender inequalities with resulting effects on earning gaps and prospects for career mobility (Chang, 2000; Kulis, 2002; Singh and Vinnicombe, 2003 \& Gold, 2003). Kazi G. (2011) conducted research on gender discrimination in job opportunities and impact of gender awareness in public sector organizations. She concluded that most women work on administrative posts or on contract with fixed pay package and no career ladder. There was no female representation in BS 20-BS 22, which clearly showed glass ceiling. Female job quota was also not fully utilized. Eagly A. et al., (2003) had conducted a research on the female leadership advantage: an evaluation of the evidence. Results were that; men were hired for those jobs which can only be performed by men and women were hired for those jobs which are suitable for women only. If women show dominancy then they were disliked. Men were promoted more in those professions where men were in majority but increased chances of quitting job for women and in such professions women show less performance as compared to men. Tower G. et al. (2009) conducted research on failing the final exam in equal employment opportunity. He concluded that the level of equal employment opportunity was disappointing. 90\% equal employment opportunity issues were not resolved. There was high level of transparency regarding equal employment opportunity practices in Anglo American universities because they put forth influence on the general public. But overall transparency was very low. Policies were not clear and vague. Abe Y. (2010) noticed in the research on the equal employment opportunity law and labor force the behavior of women in Japan and he concluded that the equal employment opportunities laws did not increase the participation of graduated married women in the regular employment. Married women are more as permanent workers as compared to single. Hence, in case of thesafe work environment along with acceptable conditions, still in many situations traveling to work may generate a level of exposure that disrupts due togender role stereotype societal norms attached with women(Ali 2012, World Bank 2006). There was increase in temporary jobs after the implementation of equal employment opportunity laws.

The above noted literature reviewed has clearly stated that the gender discrimination in selection on bureaucratic jobs is found all over the world. This situation is not encouraging picture for women.Gender inequalities in the labour market, occupations and at the workplace have quite common even today as an important characteristic of the social and economic relations in many countries. (Strachan et al ,2015).Though, uniformity between women and men is documented in the constitutions of India, Pakistan, Sri Lanka and Bangladesh, and these countries forbid discrimination on the basis of gender (Ali, 2010). 
Particularly Pakistani women, despite of their capabilities and knowledge, have been deprived of equal opportunities to pursue their career as a public servant. According to the report of UNDP, 2018 and according to the Human development Index (HID)'s, Pakistan was ranked at 150 among 189 countries. Whereas,in Pakistan many researches have been conducted to explore this perspective.Forinstance,Ahmad E. et al., (2007) conducted case study on labor supply and earning functions of educated married women. Conclusion was that women with higher level of education participated more. Increase in husband's wage reduced the probability of women participation. Women living in joint families were not socially constrained from participation. Women participation increased with the increase in wages. Earning of women depends on their profession. Teachers and lower medical staff earn less while doctors earn more. Other factors affecting earning of women were skill and education, field of work and remoteness. With regard to women participation, Sajid M. et al., (2011) conducted research on determinants of labor force participation of married women: a case study of district Gujarat. He found out that a very low participation of women in the society. The reasons were literacy status, area of residence (rural and urban), family system, family size and education of husband.

Waqas et al., (2010) conducted research on cultural barriers in women empowerment, a sociological analysis of Multan, Pakistan. Results haveshown that females were not provided same opportunities for education as males. Gender based constraints that women face was offensive behavior of managers, no respect from subordinates, less benefits and facilities like day care center, hurdle to fulfill the responsibilities both at work front and home chores and poor working environment.

Pakistani bureaucracy had inherited the colonial British Weberian model, since its inception in 1947 (Braibanti, 1966, Tanwir,M.,2014).The Public Service Commission,Pakistan, was set up for the first time in British India in 1926. After independence, the Commission was established in Pakistan in 1947 under the provision of Act 1935. At present, the commission is functioning under article 242 of the constitution of Pakistan.It recruitsonly $7.5 \%$ on open-merit while $92.5 \%$ are recruited on quota-basis (Khalid, B.S., 2010).

Sindh is the second largest province of Pakistan in term of population. It is developed region having 23 districts, more than 1000 Million industrial units, industries, road and infrastructure and high literacy ratio. The Sindh Service Public Commission(SPC) was established on 1 August 1947, fairly among all the districts disparities.It is responsible for smooth running of the affair related to the scrutiny, test, and interviews for hiring of human resources for initial regular appointment to civil posts as per the procedural guidance (SPC, 2019). The Sindh province has only 20\% quota in Federal Public Service commission, (Shezad,K.,2017)which leads to stand less participation of its population in Policy -making at federal level. 
Gender inequalities in the labour market, occupations and at the workplacehave been, and remain today, a feature of the social and economic relations in mostnations. The universality of gender inequality remains. This has major humanrights implications and is recognized as having a profound economic impact:

"People and their talents are two of the core drivers of sustainable, long-termeconomic growth. If half of these talents are underdeveloped or underutilized,the economy will never grow as it could". Indeed, "companies who fail to recruitand retain women - and ensure they have a pathway to leadership positions-undermine their long-term competitiveness" (Schwab, 2014).

The aim of this research study is to analyze gender discrimination in the selection on bureaucratic jobs in Pakistani society at Sindh provinces level, through Sindh Public Service Commission (SPSC) and to explore the similarities and differences in the selection process in Pakistani context. The key focused is to understand this issue from the employment process adopted by the Government for high cadre Government and examine the selection process of individuals through their gender lens in the province of Sindh. Under these circumstances, this research is an effort to shed light on these issues.Quality between women and men is recognized in the constitutions of India,Pakistan, Sri Lanka and Bangladesh, and these countries prohibit discriminationon the basis of gender (Ali, 2010, pp. 38-43).

\section{Research Methodology}

This is an exploratory cum comparative research study is conducted to identify the gender discrimination in appointments on Gazetted jobs-bureaucratic - through Sindh Public Service Commission.In this research extensive research and analysis of content are focused. In the extensive research superficial type of the research is conducted i.e. gender discrimination was assessed in the employment in Pakistan; therefore the researcher used the Sindh province as sample for the present study and variables are gender and employment.

The analysis of content carries out the research in an organized way. It makes the research understandable easily to everyone.Main source of data collection is through secondary and tertiary data. Thedocumentary information sourced from reports, registers, minutes of meetings, journals and books were also immensely helpful in the study. However, for this research the internal source of data collection used is internal annual reports ofSindh Public Service Commission (SPSC). 
For a further deep understanding in this research study, the researchers were used two important statistical toolsfor the analysis in terms of gender discrimination in Gazetted jobs-bureaucratic jobs through Sindh public service commission(SPSC). The researchers were utilized the above noted tools to comprehend the gender based distinctions for better understanding of the topic and presented the analysis separately, following were the statistical tools used in the study:

1- The fourth-fifths rule

2- Chi-Square for goodness of fit test.

The fourth-fifths rule is a practical device to keep an eye on serious issues regarding employment decisions. ${ }^{4}$

For this study,the application of the rule will help to know whether there is a disparate Impact in the Sindh public service commission(SPSC). This will further helpful to know thatwhether or not, the employment rate of women is according to the rule, $80 \%$ of the hiring rate for the majority group at Sindh public service commission. Hence, if the analysis shows that the percentage is less than $80 \%$ than statistical testing is needed to confirm or reject that there was an adverse impact.

Chi-square for goodness of fit test is used to know how confident we are that there are relations between the variables in the population. It calculates the expected frequency or value of each cell. This test is used to find how likely it is that two variables are associated. The Chi-square value means nothing on its own and it is meaningfully interpreted only in relation to its associated level of statistical significance. Statistical significance of Chi-square does not depend only on magnitude but also on the number of categories of the two variables (Bryman \& Bell., 2007).

In the present study two variables were used as gender and employment. Furthermore, gender was divided into two categories:male, femaleand following study hypothesis was made to investigate the issues in existing set-up of Sindh Public Service Commission (SPSC):

\section{Hypothesis}

Following hypothesis has been drawn that:

$\mathrm{H}_{1}$ : Selection rate of males is more than females through Sindh Public Service Commission (SPSC) for bureaucratic jobs.

$\mathrm{H}_{0}$ : Selection rate of males is not more than females through SPSC for bureaucratic jobs. 


\section{Results \& Discussions}

The aim of this study was to explore the position of women in the civil services with reference to Pakistan. Similarly, it is evident from the report of Sindh Public Service Commission, Annual Report of 2011 thatthere is gender discrimination against females in the appointment of Section Officer's posts. Though in the Sindh Public Service Commission exam offers equalopportunity for men and women and mainly the recruitment process based on merit at the time of employee induction but the bureaucracy as a system and its access to power and authority rests constrained to men.

\section{Analysis by the Fourth-Fifths Rule}

In this research, the fourth-fifths rule and Chi-Square for goodness of fit test were applied for monitoring number of male \& female applicants appearedin the Deputy District officer, Section officer and in combined competitive examination.

\section{Deputy District Officer (BPS-17)}

\section{Table:1}

Number of male \& female applicants in combined competitiveexaminations (Deputy District Officer B-17)

\begin{tabular}{|l|c|c|}
\hline & Male & Female \\
\hline Total Applicants & 400 & 204 \\
\hline Appointed Applicants & 40 & 3 \\
\hline
\end{tabular}

Source: Sindh Public Service Commission, Annual Report 2011.

Here majority group is male \& minority group is female

Male

Appointed Male Applicants

Total Male Applicants

$40 / 400=10 \%$

Rate of minority /Rate of Majority

$1.47 / 10=14.7 \%$

$14.7 \%<80 \%$
Female

Appointed Female Applicants

Total Female Applicants $3 / 204=1.47 \%$

The above statistic showed that only $14.7 \%$ female were appointed, which is much less than male appointment $(80 \%)$, therefore there is huge gender discrimination against females in the appointment of Deputy District Officer's posts. 
Moreover, this results further yielded by the application of thefourth-fifths rule showed that in year 2011, in combined competitive examinations for the posts of Deputy District Officer, appointment of the minority group(females) was only $14.7 \%$ percent of the appointment of majority group(males). As the appointment of minority group $(14.7 \%)$ is less than $(80 \%)$ of the appointment of majority group, hence there was gender discrimination against females in these appointments.

\section{Section Officer (B-17)}

\section{Table:2}

Number of male $\&$ female applicants in combined competitive examinations (Section Officer B-17)

\begin{tabular}{|l|c|c|}
\hline & Male & Female \\
\hline Total Applicants & 113 & 22 \\
\hline Appointed Applicants & 60 & 4 \\
\hline
\end{tabular}

Source: Sindh Public Service Commission, Annual Report 2011.

Here majority group is male \& minority group is female.

Male

Appointed Male Applicants

Total Male Applicants

$60 / 113=53 \%$
Female

Appointed Female Applicants

Total Female Applicants

$$
4 / 22=18.18 \%
$$

\section{Rate of minority /Rate of Majority}

$18.18 / 53=34 \%$

$$
34 \%<80 \%
$$

Keeping in view the above noted figure, it is revealed that as $34 \%$ is less than implication of the fourth-fifths rule or $(80 \%)$, therefore it can besaid that there is gender discrimination against females in the appointment of Section Officer's postsin the province of Sindh.Furthermore, the application of fourth and fifths rule showed that in year 2011, in combined competitive examinations for the posts of Section Officer, appointment of the minority group (females) was 18.18 percent of the appointment of majority group (males). As the appointment of minority group $(18.18 \%)$ is less than $(80 \%)$ of the appointment of majority group, thus, the study results bring the information that there was gender discrimination against females in these appointments and the government prefers to employ the male in the bureaucratic jobs. 


\section{Analysis by Chi-Square Goodness of Fit Test}

\section{Combined Competitive Examination}

Table:3

Number of male $\&$ female applicants in combined competitive examination

\begin{tabular}{|l|c|c|c|}
\hline & Male & Female & Total \\
\hline Observed Frequency & 121 & 7 & 128 \\
\hline Expected Frequency & 76.8 & 51.2 & 128 \\
\hline
\end{tabular}

Source: Sindh Public Service Commission, Annual Report 2011.

$$
\begin{aligned}
\chi^{2}= & \sum \frac{\left(O_{i}-E_{i}\right)^{2}}{E_{i}} \\
= & \frac{(121-7)^{2}}{7}+\frac{(7-51.2)^{2}}{51.2} \\
= & \frac{(114.2)^{2}}{76.8}+\frac{(-44.2)^{2}}{51.2}=\frac{12996}{76.8}+\frac{1953.64}{51.2} \\
& =169.21875+38.15 \\
& =207.36875
\end{aligned}
$$

We test at the $5 \%$ level of significance $(\alpha=0.05)$, the critical value of $\chi^{2}$ with one degree of freedom is 3.84 . As $207.36875>3.84$.

On the basis of these statistical findings, it is revealed that the null hypothesis has to be rejected and the alternative hypothesis isaccepted in the present study that"Selection rate of males is not more than females through SPSC for bureaucratic jobs". Therefore, theapplication of statistical: the fourth-fifths rule and chi-Square for goodness of fit test,both test results has confirmed that the political, social and economic performance of women is seen and there is huge gender discrimination against females in the appointment of Deputy District Officer's posts and section officers post at Sindh Province level as the.

Gender Discrimination in the appointment on the bureaucratic jobs was assessed also through the Chi-Square goodness of fit test. The present study is premised on the hypothesis that selection rate of males is not more than females through SPSC for bureaucratic jobs. Results yielded by the test showed that $\chi^{2}=207.368$ which was compared against critical value of $\chi^{2}$ with one degree of freedom at $5 \%$ level of 
significance, the value of which is 3.84 . As 207.368 is much more than 3.84 , which showed that there was huge discrimination against females in the appointment of bureaucratic jobs. Hence, this statistical test was also confirms that there is a noticeable gender-based discrimination in the province.

\section{Conclusions}

In any patriarchal society women role is generally limited to household affairs as a subordinate and this situation is quite common in Pakistani society. Women participation in political, economic, and social sphere is not cheered. Descriptive statistics of the present study has indorsed thefindings of previous studies like (Qureshi, S, et al., 2013), which reported the unadulterated gender differences in bureaucratic jobs. In all spheres of life,Pakistani women have been discriminated, negate equality to women, and seek to exclude them from the public sphere (Bhattacharya, 2013).Yet, women have only been included as supplements by being given a nominal quota in local government. Likewise, entrance to and control over resources, entitlement to rights and power sharing are still unequally distributed between men and women (Saigol, 2011). Hence, women presences are likely inactive which endorses most common perception thatwomen should stay out of politics. The elements of class and patriarchal dominance stand toconsistently oppress women.

The present study revealed that the political, social and economic performance of women is seen and there is huge gender discrimination against females in the appointment of Deputy District Officer's postsand section officer's post at Sindh Province level.The result of present study confirms the result of a qualitative study conducted by Fiza Ali(2013)at Lahore to scrutinizethe women working problems in Pakistani organizations and suggests that it is very important to address socio-cultural issues fronting women in order to support gender equality in organizations or workplace. Similarly, it is evident from the report of Sindh Public Service Commission, Annual Report of 2011 thatthere is gender discrimination against females in the appointment of Section Officer's posts.Though in the Sindh Public Service Commission exam offers equalopportunity for men and women and mainly the recruitment process based on merit at the time of employee induction but the bureaucracy as a system and its access to power and authority rests constrained to men.

Based on the result of the study,it can be concluded thatthe recruitment attitude towards women's access into politics especially inthe appointment on the bureaucratic jobs has begun to change from that of total rejection to limited encouragement at Sindh level.Although, the speed of this socially transformative trend is in slow the bureaucracy jobs due to the social and culturalinfluences. In this regard an attitudinal change is required in both men and women as women face more problems as compared to the 
man.However, the present study did not find out the difference in quality of job performance on the basis of the gender.

\section{Recommendations}

On the basis of the above-noted results, it is suggested that a strong advocacy campaign is needed to encourage women participation in bureaucratic jobs. In this context, a gender equivalence perspective should be institutionalized in all sphere of life. The perception that women are meant for household activities and rearing children needs to be transformed into a feeling of equal partnership of women and men at all level especially in recruitment process and an equal employment opportunity laws must be followed.

This research strongly recommends that to formulate gender-sensitive and supportive governmentpolicies. The government should integrate a gender perspective into any public policy as women's representation constitutes half the population in the Country. It is also suggested that there is a dire need for real empowerment of women and to strengthen this recent trend as viewed in the present study.Women's entry into politics especially in appointment on the bureaucratic jobs has begun at Sindh level, through orientation courses and training programmersfor officials and elected representatives, both men and women. Likewise, for better economic growth it is necessary for the State to follow gender equity policy.

\section{End Notes}

1. It provides uniform guidelines for employers to follow in administering promotionalexaminations.

2. According to fourth-fifths rule, discrimination occurs when :

- More than fourth-fifths of a company's work force are majority members.

- Less than fourth-fifths of applicant in minority group are accepted for employment in a job category.

- The percentage of minorities group in and any ethnic or gender group is less than of fourth-fifths of the percentage in the surroundinglabour force.

- The selection rate of any minority group is less than fourth-fifths of the selection rate for the highest group.

3. Duke Power Company was a public utility corporation.On December 14, 1970, a court case argued before the Supreme Court of the United States. It concerned employment discrimination and the court ruled that the company's employment requirements did not pertain to applicants' ability to perform the job, and so were discriminating against black employees. Furthermore, the court ruled that, even if the motive for the requirements had nothing to do with racial discrimination, 
they were nonetheless discriminatory and therefore illegal. In its ruling, the Supreme Court held that employment tests must be "related to job performance."

4. Generally, this statistical model is suitable for the condition where the score of each applicant is measured as a random sample from one common distribution of scores.

\section{References}

Abe, Y. (2010). Equal Employment Opportunity Law and the Gender Wage Gap in Japan: A Cohort Analysis. Journal of Asian Economics, vol.21:2, pp.142-155. doi:10.1016/ j.asieco.2009.12.003.

Abe, Y. (2011). The Equal Employment Opportunity Law and Labor Force Behavior of Women in Japan. Journal of the Japanese and International Economies, vol.25:1, pp.39-55.

Ahmad E. \& Hafeez A. (2007) Labor Supply \&Earning Functions of Married Women: A Case Study of Northern Punjab, The Pakistan Development Review, vol.46:1, pp.45-62.

Ali, F. (2010).A comparative study of EEO in Pakistan, India and Bangladesh. In M. Ozbilgin \& J. Syed (Eds), Managing Gender Diversity in Asia: A Research Companion, Cheltenham, UK: Edward Elga., pp.32-53.

Ali, F. \& Knox, Angelangela (2008). Pakistan's Commitment to Equal Employment Opportunity for Women: A Toothless Tiger? International Journal of Employment Studies, vol.16:1, pp.39-58.

Ali, Faiza (2013). A Multi-Level Perspective on Equal Employment Opportunity for Women in Pakistan, Equality, Diversity and Inclusion: An International Journal, vol.32:3, pp.289-309, https://doi.org/10.1108/EDI-12-2012-0110

Ali, K. A. 2012. Women, Work and Public Spaces: Conflict and Coexistence in Karachi's Poor Neighborhoods. International Journal of Urban and Regional Research, vol.36:3, pp.585-605.

Arulampalam W, Booth AL, \& Bryan ML. (2007). Is there a Glass Ceiling OverEurope?:Exploring the Gender Pay Gap Across the Wage Distribution. Industrial and Labor Relation Review, vol.60:2, pp.163-186. 
Bhattacharya, Sanchita (2013). Pakistan: Woman: Unseen, Unheard, Targeted, [Online: web] Accessed 12 Feb. 2018, URL: http://www.satp.org/satporgtp/sair/Archives/ sair12/12_2.Htm\#assessment2.

Bryman Alan., Bell Emma. (2007). Business Research Methods, $2^{\text {nd }}$ Edition, Oxford University Press Inc., New York, pp. 367-370.

Braibanti, R. (1966). The Higher Bureaucracy of Pakistan. Ed, Asian Bureaucratic Systems Emergent from the British Imperial Tradition. Durham, Duke University Press, Durham, NC, pp.209-354.

Chang, M. (2000).The Evolution of Gender Segregation Regimes.The American Journal of Sociology, vol.105, pp.1658-1701.

Decenzo, David \& Stephen, Robbins (1996). Human Resource Management, $5^{\text {th }}$ ed., John Wiley \& Sons, New York, pp.31-88.

Dressler G. (2007). Human Resource Management, $10^{\text {th }}$ edition, Prentice Hall, New Jersey.

Delavande, A. \& Zafar, B. (2013). Gender Discrimination and Social Identity: Experimental Evidence from Urban Pakistan. New York: Federal Reserve Bank of New YorkStaff Reports, no. 593, pp-1-37.Accessed on $27^{\text {th }}$ Feb, 2018 URL: https://www.newyorkfed.org/medialibrary/media/research/staff_reports/sr593.pdf.

Eagly, A. Carill (2003). The Female Leadership Advantage: An Evaluation of the Evidence, The Leadership Quarterly, vol.14, pp.808-828.

European Union (2014). Tackling the Gender Pay Gap in the European Union. Luxembourg: Publications Office of the European Union.

Gold, A. (2003). Enterprise Culture, Equity and Gendered Change inCommonwealth Higher Education, Williams Gareth (ed.) the EnterprisingUniversity: Reform, Excellence and Equity, Burkingham: Open University Press.

Government of Sindh (2011) Annual Report 2011, Sindh Public Service Commission, Pakistan, pp.31-70.

Iqbal, H., Afzal, S. \& Inayat, M. (2012).Gender Discrimination: Implications forPakistan Security. IOSR Journal of Humanities and Social Science (IOSRJHSS), 1(4), PP 1625. ISSN: 2279-0845 PP 16-25 
Imasogie, M.O. (2010) OIDA International Journal of Sustainable Development 02: 05 pp.11-18.

Jabeen, Nasira\&Iqbal, Muhammad Zafar (2010). Gender and Local Governance in Pakistan: Promoting Participation through Capacity Building, South Asian Studies: A Research Journal of South Asian Studies, vol.25:2, pp.255-281.

Kazimi, Muhmmad Reza (2007). A Concise History of Pakistan, Pakistan Studies, Oxford University Press, Karachi, pp. 47-55.

Kazi, G. (2011).Gender Discrimination in Job Opportunities \&Impact of Gender Awareness in Public Sector Organizations, Planning \& Development Division/Commission, Government of Pakistan.

Khalid B. Sayeed., (2010), Pakistan: the formative phase, 1857-1948, 2nd Edition, Oxford University Press, Karachi. pp. 258-268.

Kabir, S.L. (2013). Key issues in women's representation in bureaucracy: Lessons from South Asia. Public Organization Review, vol.13:4, pp.427-442.

Kulis, S., Sicotte, D. \& Collins, S. (2002). More than a Pipeline Problem: Labor Supply Constraints and Gender Stratification Across Academic Science Disciplines. Research in Higher Education, vol.43:6, pp.657-691.

Luis R., David B. Balkin and Robert L. Cardy Gomez-Mejia (2005) Managing human resources, $4^{\text {th }}$ edition, New Jersey: Prentice-Hall, I 89-186.

Mor Barak, Michelle E. (2011). Managing Diversity: Towards a Globally Inclusive Workplace, $2^{\text {nd }}$ edition, Thousand Oaks, CA: Sage Publications Inc. pp.286-292.

Noe, Hollenbeck, Gerhart, Wright (2001) Human Resource Management: Gaining a Competitive Advantage, $4^{\text {th }}$ edition, McGraw Hill Companies Inc, New York, 5-120.

Qureshi S., Safdar Abbas., Safdar, R. \& Zakar, R. (2013). Gender Responsive Budgeting in Pakistan: Scope and Challenges, Journal of the Research Society of Pakistan,vol.50:1, pp.1-26.

Sajid M., Maqsood F., Maqsood S. \& Afzal I. (2011). Determinants of Labor Force Participation of Married Women: A Case Study of District Gujarat, Academic Research International, vol.1:3, pp.254-263. 
Saigol, R. (2011). Women's Empowerment in Pakistan. Islamabad: Aurat Publication and Information Services Foundation.

Schwab, K. (2014). Preface. In World Economic Forum. The Global Gender Gap Report 2014. P:5 Retrieved 4 March 2015, from http://www3.weforum.org/docs/ GGGR14/GGGR_CompleteReport_2014.pdf.

Singh, V. \& Vinnicombe, S. (2003). The 2002 female FTSE Index and Women Directors.Woman in Management Review, vol.18:17, pp.349-358.

Shauka, S., Siddiquah, A. \& Pell, W.A. (2014). Gender Discrimination in Higher Education in Pakistan: A Survey of University Faculty. Eurasian Journal of Educational Research, vol.56, pp.109-126 http://dx.doi.org/10.14689/ejer.2014.56.2

Shahzad, K.Ahmad(2017). Crisis of Governance in the Bureaucracy of Pakistan: A Study of Administrative Ramifications with Apposite Policy Recommendations, ISSRA PAPERS ,National Defence University,Pakistan,vol:ix:11,p.26.

Sindh Public Commission, (2019).Introduction to Sindh public Commission. http://www.spsc.gov.pk/

Strachan Glenda, Adikaram, A. \& Kailasapathy P. (2015). Gender (In) Equality in South Asia: Problems, Prospects and Pathways, South Asian Journal of Human Resources Management 2(1) Sage Publication, India, and pp: 1-11. https://doi.org/10.1177/2322093715580222

Tanwir, Maryam (2014).Gender Neutrality and the Pakistani Bureaucracy,Journal of International Women's Studies, vol.15:2, pp.143-164.

Tower G., Julie, Brenda, \&Emily, Spence (2009) Failing the Final Exam in Equal Employment and Opportunity, Journal of Diversity Management, vol.4:1, pp.25-28.

The Global Gender Gap Report: 2016. Geneva: World Economic Forum; 2016.

UNDP (2016). Human Development Report 2016, Accessed on 17 Feb, 2018,URL: https://www.pakistantoday.com.pk/2016/01/25/pakistan-ranks-121st-of-155-ongender-inequality-index-undp.

UNDP (2018). Human Development Report 2018, Accessed on $10^{\text {th } J a n, ~ 2019, ~}$ URL:https://www.pakistantoday.com.pk/2016/01/25/pakistan-ranks-121st-of-155on-gender-inequality-index-undp/ 
UNICEF (2012) Situation Analysis of Children and Women in Pakistan, NationalReport, Pakistan.P-36.URL: https://www.unicef.org/pakistan/National_Report.pdf

United Nations, Committee on the Elimination of Discrimination against WomenCEDAW, (2011).Concluding comments of the Committee on the Elimination of Discrimination against Women: Pakistan, 38th session, 14 May-1 June 2007, UN document CEDAW/C/PAK/CO/3, 11 June 2007.ULR:http://www2.ohchr.org/english/bodies/cedaw/docs/54/CEDAW-CPAK-4.pdf

Waqas, Fani \& Afzal, Yasin (2010). Cultural Barriers in Women Empowerment, European Journal of Social Sciences, vol.18:1, pp.147-154.

World Bank. 2006. Women's Work and Movement into the Public Sphere. World Bank Group pp.1-21 Accessed on 24 ${ }^{\text {th }}$ Feb, 2018, URL: http://siteresources.worldbank.org/PAKISTANEXTN/Resources/2930511146639350561/CGA-Chapter-5.pdf.

World Economic Forum (2017) The Global Gender Gap Report 2017, Accessed on $24^{\text {th }}$ Feb, 2018 URL: http://www3.weforum.org/docs/WEF_GGGR_2017.pdf

Dr. Zahid Ali Channar is Dean, Faculty of Management, Business Administration \& Commerce, Sindh Madressatul Islam University, Karachi.

Dr. Sakina Riaz is an Assistant Professor in the Department of Social Work, University of Karachi.

Saleem Raza Quresh is PhD Scholar in the Department of Management Sciences, Isra University Hyderabad. Sindh. 